\title{
THE CONSTITUTIONALITY OF REINDICTING SUCCESSFUL PLEA-BARGAIN APPELLANTS ON THE ORIGINAL, HIGHER CHARGES
}

The overwhelming majority of criminal defendants are convicted and sentenced as a result of guilty pleas which are commonly offered pursuant to a plea bargain. ${ }^{1}$ In most of these cases acquiescence to a plea bargain will effectively bar appeal of any error in the conviction procedure. To illustrate, a defendant charged with two counts of selling narcotics agrees to plead guilty to the lesser offense of possession of narcotics; the decision to plead was induced by the prosecutor's false statement that the mandatory penalty for sale of narcotics is life imprisonment. After serving several months in prison, the defendant learns that he may have grounds for challenging the validity of his guilty plea on the theory that the prosecutor's false advice constituted coercion. In many jurisdictions, including California, the defendant would be well advised to forego his appeal because a successful reversal might lead to reinstatement of the original, higher charges and conviction for a more serious offense than the conviction which had been invalidly obtained. ${ }^{2}$

The central issue raised by the defendant's dilemma is whether reinstatement of the original charges should be permitted upon reversal of a conviction based on a negotiated guilty plea. Federal authorities are split on this point. In Mullreed v. Kropp ${ }^{3}$ the issue came before the Sixth Circuit Court of Appeals in the context of a reversal of a plea-bargained conviction. The court held that after a successful appeal from a conviction based on a guilty plea, the defendant could only be retried on the charge for which he had been convicted. ${ }^{4}$ In

1. In the federal district courts, excluding the District of Columbia and three territories, $85 \%$ of the criminal couvictions obtained in fiscal year 1972 were based on guilty pleas or pleas of nolo contendere. See 1972 ANNUAL REPORT OF THE Dirzctor OF THE ADMINISTRATTVE OFFICE OF THE UNITED STATES COURTS 381. In Califoraia, 82\% of all defendants convicted of felonies in 1972 pleaded guilty. See 1972 Buresu of Crominal Statistics, Division of Law Enforcement, Departmant of Justice, State of California, Crime and Delinguency in California 42 (1973). Although precise figures indicating the proportion of guilty pleas submitted pursuant to plea bargains are not available, all authorities agree that the primary explanation of the prevalence of guilty pleas is the prosecutor's willingness to negotiate charging and sentencing concessions in return for guilty pleas. See, e.g., Brady v. United States, 397 U.S. 742, 752 (1970).

2. E.g., People v. Harper, 32 Mich. App. 73, 188 N.W.2d 254 (1971), In re Sutherland, 6 Cal. 3d 666, 672, 493 P.2d 857, 861, 100 Cal. Rptr. 129, 133 (1972).

3. 425 F.2d 1095 (6th Cir. 1970).

4. Id. at 1102 . 
the Tenth Circuit the same issue arose in Ward v. Page $e^{5}$ in a slightly different factual context, ${ }^{6}$ and the court allowed reprosecution on the original, higher charges. ${ }^{7}$

This Comment will appraise the rule permitting reprosecution on the original, higher charges in relation to three distinct constitutional principles: due process, double jeopardy, and equal protection. ${ }^{8}$ The due process discussion will center on the need to protect defendants from the imposition of judicial and prosecutorial vindictiveness for having sought appellate review. The issue of judicial vindictiveness has been most extensively considered in the context of harsher sentences after retrial of criminal defendants who had won an appeal from their original conviction. North Carolina v. Pearce ${ }^{9}$ is the leading case. There the Supreme Court unequivocally stated that a policy of imposing harsher sentences in retaliation for taking an appeal is a violation of due process. The analogy of judicial vindictiveness to prosecutorial vindictiveness in the form of reindictment on the original, higher charges after a successful appeal from a plea-bargain conviction argues for extending the reasoning of North Carolina v. Pearce ${ }^{10}$ to the pleabargain appellant.

The courts which have ruled on the issue liave rejected the vindictiveness argument on contract-type reasoning. ${ }^{11}$ The defendant's taking an appeal and obtaining a new trial is analogized to a revocation or rescission of the bargain, purportedly justifying the prosecutor's decision to assert the status quo ante by reindicting the defendant on the original, higher charges. The validity of introducing contract principles to avoid facing the possibility of prosecutorial vindictiveness will be evaluated first. Then, in deference to the widespread appeal of the contract theory, that theory will be refined to incorporate the gross disparity in bargaining power between the prosecutor and the defend-

5. 424 F.2d 491 (10th Cir. 1970), cert. denied, 400 U.S. 917 (1970).

6. The defendant decided to negotiate a guilty plea arrangement after the trial had actually begun. Ward v. Page, 238 F. Supp. 431, 432-33 (E.D. Okla. 1965).

7. Ward v. Page, 424 F.2d 491, 493 (10th Cir. 1970), cert. denied, 400 U.S. 917 (1970). California's practice of treating reversal of a guilty plea as if it were a withdrawal of the plca returning the parties to the status quo ante is consistent with the result in Ward v. Page, supra. See In re Sutherland, 6 Cal. 3d 666, 672, 493 P.2d 857, 861, 100 Cal. Rptr. 129, 133 (1972).

8. A similar organizational scheine can be found in Van Alstyne, In Gideon's Wake: Harsher Penalties and the "Successful" Criminal Appellant, 74 YALE L. J. 606 (1965) [hereinafter cited as Van Alstyne]. Van Alstyne's incisive article contains the seeds of several of the arguments which appear in this Comment. See also Note, Unconstitutional Conditions, 73 HARv. L. Rev. 1595 (1960).

9. 395 U.S. 711 (1969).

10. Id.

11. See, e.g., United States ex rel. McMann v. Willianis, 436 F.2d 103 (2d Cir. 1970), cert. denied, 402 U.S. 914 (1971). 
ant. This refinement of the conventional contract approach of the courts reveals a contract of adhesion and demonstrates the need for a rule which permits a plea-bargain defendant to pursue an appeal without fear of reindictment on the original, higher charges.

The double jeopardy section focuses on the reasoning of Mullreed v. Kropp,$^{12}$ the Sixth Circuit decision which prohibits reprosecution of a successful plea-bargain appellant on the original, higher charges. Mullreed is premised on the notion that a judge's failure to convict a defendant of the higher offense when presiding over the submission of a guilty plea on the lesser offense constitutes an imphed acquittal. In accord with the double jeopardy principles growing out of jury trials, the Mullreed court invokes the rule that the finding of an implied acquittal bars reprosecution on the higher charge. The Mullreed analysis is criticized for extending the application of the implied acquittal concept into a context where the fact-finding process is primarily designed to protect against overcharging. If satisfied that the plea is voluntary, the judge at a guilty plea proceeding has little, if any, incentive to press for further evidence that would justify conviction on the maximum charge in the indictment. By contrast, the jury does actually choose not to convict on the higher offense since it weighs the evidence developed at trial for the purpose of classifying the defendant's conduct in relation to all the charges contained in the indictment.

The Mullreed preoccupation with an implied acquittal is also criticized for its avoidance of the threshold question of whether jeopardy ever attached on the higher offense. Given that a judge at a guilty plea proceeding is never asked to hear the evidence in support of the higher charge, traditional analysis would conclude that jeopardy never attached on the higher offense. In sum, the Mullreed discussion illustrates the general inadequacy of double jeopardy as a doctrinal approach to the scope-of-reprosecution problem in plea-bargain cases.

Although equal protection has generally been ignored or rejected by the Supreme Court ${ }^{13}$ as an analytical approach to the scope-of-reprosecution issue, this Comment concludes that it offers the unost exhaustive insight into the conflicting interests at stake. Three standards of equal protection review are used to weigh these interests. The permissive reasonableness test introduces the spectrum of state interests potentially served by a rule which permits reprosecution on higher charges. Among these are the discouragement of frivolous appeals, the maintenance of plea bargains as a procedure to avoid trials, deterrence of crime, and the retention of tactical advantages associated with prosecuting on the maximum offense. Permitting reprosecution on higher

12. 425 F.2d 1095 (6th Cir. 1970).

13. North Carolina v. Pearce, 395 U.S. 711, 722-23 (1969). 
charges arguably meets the reasonableness standard by virtue of the tactical advantage it affords the prosecutor.

Reprosecution on higher charges, however, clearly fails to satisfy the other two possible standards of equal protection review, strict scrutiny and intensified means scrutiny. The fundamental character of the defendant's interest in appeal justifies the utilization of the strict scrutiny standard. As is normally the case, the state's interests are not sufficiently compelling to overcome the presumption of unconstitutionality which accompanies strict scrutiny. Nor is the rule able to withstand the intensified means scrutiny test. That standard requires a substantial relationship between the means adopted and the various objectives of the government. Application of this test to the scopeof-reprosecution problem demonstrates that the rule has an impact which is both overinclusive and underinclusive. Indeed, the tendency of the rule to punish those defendants who have the most meritorious appeals underscores its shortcomings in this regard.

The conclusion briefly summarizes the analysis and discusses some unexplored practical objections to limiting the scope of reprosecution after successful appeal froin a plea-bargain conviction. The conclusion also emphasizes that the appellate safeguards available to plea-bargain convicts constitute the only appellate safeguards available to the great majority of the prison population.

I

\section{Due Process}

\section{A. Vindictiveness}

The Supreme Court's recognition that judicial vindictiveness at retrial constitutes a violation of due process first appeared in North Carolina v. Pearce. ${ }^{14}$ The decision disposed of two cases. In one case the defendant, Pearce, had been convicted by a jury of assault with intent to commit rape and sentenced to a prison term of 12 to 15 years by the trial judge. After successfully appealing on the constitutional ground that an involuntary confession had been admitted in evidence, Pearce was retried on the same charge and sentenced by the trial judge for an additional eight years. When added to the time Pearce had already spent in prison, the new sentence amounted to a term longer than that which had been originally imposed. In the compamion case, Simpson $v$. Rice, ${ }^{15}$ the defendant Rice had pleaded guilty to four separate charges of burglary. ${ }^{16} \mathrm{He}$ was sentenced to prison

14. 395 U.S. 711 (1969).

15. Id.

16. Rice was probably the beneficiary of a plea bargain. United States ex rel. 
terms aggregating ten years. Subsequently the judgment was overturned on the ground that Rice had been denied his constitutional right to counsel. On retrial Rice was convicted of three of the original charges and sentenced to prison terms totaling 25 years.

In both cases the question before the Court was the constitutionality of imposing harsher punishment on a defendant who had successfully appealed his original conviction. Relying on the due process clause of the fourteenth amendment, the Supreine Court decided "that vindictiveness against a defendant for having successfully attacked his first conviction inust play no part in the sentence he receives after a new trial." ${ }^{17}$ The Court did not treat the harsher sentences imposed on Pearce and Rice as evidence of vindictiveness per se. Instead the Court concluded that in the absence of any affirmative evidence on the record justifying the harsher sentences meted out to Pearce and Rice, the sentencing judges failed to carry the burden of proving that they did not act vindictively to punish the defendants for having prevailed on appeal. ${ }^{18}$

The Court was primarily concerned that a policy of retaliatory sentencing would "chill" or impair the defendant's right of access to the avenues of appeal established by the state. ${ }^{19}$ Acutely aware of the difficulty of proving retaliatory motive, the Court felt impelled to establish a prophylactic evidentiary rule as a constitutional requirement. $^{20}$ In effect, the Supreme Court created a presumption that a

Williams v. McMann, 436 F.2d 103, 107 (2d Cir. 1970) (Hays, J., concurring), cert. denied, 402 U.S. 914 (1971). The majority in Williams v. McMann disputed Judge Hays' inference of a plea bargain by citing the fact that the Supreme Court's opinion in Pearce contains no mention of an "express agreement." $1 d$. at 106, n.7. Yet the majority fails to acknowledge that before plea bargaining was approved by the Supreme Court in Brady v. United States, 397 U.S. 742 (1970), it was well known that courts accepting guilty pleas commonly created a record denying the existence of a bargained-for plea. People v. West, 3 Cal. 3d 595, 605-09, 477 P.2d 409, 414-17, 91 Cal. Rptr. 385, 390-93 (1970). Given this widespread practice of concealing plea bargains, the terms of an express agreement would not be likely to appear on the record before the Supreme Court. The reasonableness of Judge Hays' inference is based on the relative leniency of the sentence when the defendant pleaded guilty on four counts of burglary as compared with the severity of the sentence handed down after Rice was retried on three counts of burglary.

The likelihood that Rice was a plea-bargain appellant raises a substantial equal protection question which will be discussed later in the text. See text accompanying notes 172 to 179 infra.

17. North Carolina v. Pearce, 395 U.S. 711, 725 (1969).

18. Id. at 726 .

19. Id. at 725. Owing to the oft-cited dictum of McKane v. Durston, 153 U.S. 684,687 (1894), courts have uniformly concluded that there is no constitutionally guaranteed right of appeal. But where a state grants statutory access to appcal, courts have consistently stated that unreasonable impediments to the avenues of appeal which have been made available are unconstitutional as violations of due proccss. Chaffin v. Stynchcombe, 412 U.S. 17, 24 n.11 (1973).

20. The Court in North Carolina v. Pearce, 395 U.S. 711 (1969), declared that: 
harsher sentence following an appeal and retrial is vindictively motivated. The Court placed the burden of disproving vindictiveness on the government and stipulated that rebuttal of the presumption could be based only on conduct of the defendant which occurs after the original sentencing. ${ }^{21}$

In a recent decision, Chaffin $v$. Stynchcombe, ${ }^{22}$ the Court considered the scope of the Pearce rule in the context of harsher jury sentencing on retrial. The Court articulated three preconditions for finding vindictiveness on the part of a sentencing authority: ${ }^{23}$

1. Knowledge of the prior sentence;

2. Determination of the second sentence by the same judicial authority whose handling of the prior trial was sufficiently unacceptable to require a reversal of the conviction;

3. Institutional interest in limiting what are perceived to be meritless appeals.

Because the jury as a sentencing authority does not meet any of these criteria, the Court refused to extend North Carolina v. Pearce $e^{24}$ to harsher jury sentencing on retrial. ${ }^{25}$ Nevertheless it did establish these

[W]henever a judge imposes a more severe sentence upon a defendant after a new trial, the reason for his doing so must affirmatively appear. Those reasons mnst be based upon objective informatiou concerning identifiable conduct on the part of the defendant occurring after the time of the original sentencing proceeding. And the factual data upon which the increased sentence is based must be made part of the record, so that the constitutional legitimacy of the increased sentence may be fully reviewed on appeal.

Id. at 726. See Chaffin v. Stynchcombe, 412 U.S. 17, 37 (1973) (Stewart, J., dissenting).

21. North Carolina v. Pearce, 395 U.S. 711, 726 (1969).

22. 412 U.S. 17 (1973).

23. Id. at $26-27$.

24. 395 U.S. 711 (1969).

25. Chaffin v. Stynchcombe, 412 U.S. 17 (1973) was a 5-4 decision which inspired three separate dissenting opinions. Justice Douglas's dissent alludes to his dissenting opinion in Moon v. Maryland, 398 U.S. 319, 321 (1970) (per curiam) where he argued that the double jeopardy clause of the fifth amendment bars harsher punishment at retrial. But, as the majority in Chaffin noted, this point was clearly settled against Justice Douglas by the decision in North Carolina v. Pearce, 395 U.S. 711, 720 (1969).

Justice Stewart's dissent offers the most cogent attack on the majority's reasoning. He contends that allowing the prosecutor to argue for a harsher sentence without restricting the maximuin permissible sentence to the original sentence will create an opportunity for the prosecutor to retaliate against the defendant for having won an appeal. The majority responds to Justice Stewart by stating that the prosecutor may have a legitimate tactical motive for asking the jury to impose the maximum sentence. But as Justice Stewart correctly points out, the test under North Carolina $v$. Pearce, supra, is not the existence of some legitimate motive, but the absence of any vindictive motive. See note 26 infra for a more detailed discussion of Stewart's criticism.

Unlike Justice Stewart, Justice Marshall in his dissent does not limit himself to the position that the increased jury sentence may reflect vindictiveness. $\mathrm{He}$ argues that the higher sentence per se places an unconstitutional burden on the right to jury 
criteria as general prerequisites for determining if judicial vindictiveness might have motivated more severe punishment following a successful appeal.

The possibility that the prosecutor, as well as the judge, may act vindictively against a defendant who has obtained a reversal of his conviction was expressly acknowledeged by the majority in Chaffin $v$. Stynchombe. ${ }^{26}$ The Chaffin prerequisites to a presumption of vindictiveness are as applicable to a prosecutor remdicting after an appeal as they are to a judge resentencing after appeal. The prosecutor, like the judge, is aware of the prior sentence. The determination of the charges on which the defendant will be retried is frequently in the hands of the same prosecutor whose conduct at the earlier trial was sufficiently unacceptable to require reversal. ${ }^{27}$ And both the prosecutor and the judge share an institutional interest in discouraging what they perceive to be meritless appeals. ${ }^{28}$ Thus, the prosecutor who seeks to press higher charges against the defendant at retrial both satisfies the preconditions for vindictiveness set out in Chaffin v. Stynch$c o m b e^{29}$ and threatens the same deterrence of appeals which was proscribed in Pearce. ${ }^{30}$

trial by discouraging appeals which would result in a new trial. Marshall relies principally on United States v. Jackson, 390 U.S. 570 (1958), which requires that burdening the right to jury trial with the risk of higher punishnent nust be justified by the state as a necessity. The majority in Chaffin $v$. Stynchcombe, supra, evaded application of the necessity test by asserting that the risk of heavier punishment for successful appellants is so remote that it does not significantly deter prospective appellants. 412 U.S. at 33-35. The majority's assertion logically defuses Marshall's attack, but that assertion is a highly questionable premise. See note 130 infra.

26. 412 U.S. 17, 27 n.13 (1973). The Court relies on United States $c x$ rcl. Williams v. McMann, 436 F.2d 103, 105-06 (2d Cir. 1970), cert. denied, 402 U.S. 914 (1971). Close examination of the Second Circuit's opinion slows that it misapplied North Carolina v. Pearce, 395 U.S. 711 (1969), to prosecutorial vindictiveness. In Williams, supra, the court stated that:

Pearce would have application, if a prosecutor for no valid reason charged a defendant whose first conviction had been set aside, with a more serious offense based upon the same conduct.

436 F.2d at 105. This statement implies that a prosecutor who reindicts on the more serious charge for some valid reason would not fall within the Pearce rule. But Pearce is more stringent. The Court did not ask if the judge was motivated by some valid reason counterbalancing the possibility of vindictiveness. Rather it required that the judge's motives, valid or otherwise, be completely purged of any vindictiveness. Chaffin v. Stynclicombe, 412 U.S. 17, 35-38 (1973) (Stewart, J., dissenting). If Pearce is applied to prosecutors as well as judges, the same standards would apply and a valid reason to reindict for a inore serious offense would not take the prosecutor out of the scope of the rule.

27. See Chaffin v. Stynchiconibe, 412 U.S. 17, $35-38$ (1973) (Stewart, J., dissenting).

28. Id. at 36.

29. Id. at 26-27.

30. The prisoner's overriding concern is the avoidance of increased punishment, whether that greater punishment flows from the prosecutor's seeking retrial on a 
Notwithstanding this analogy appellate courts have been reluctant to find that the prosecutor who reindicts the plea-bargain appellant on the original, higher charges was motivated by vindictiveness. ${ }^{31}$ Rather the courts have assumed that principles of contract law operate to remove the taint of vindictiveness from the prosecutor's action. ${ }^{32}$ Judge Kaufman's opinion in United States ex rel. Williams v. Mc$M a n n,{ }^{33}$ a 1970 decision of the Second Circuit, embodies a forthright statement of the contract theory as applied to the plea-bargain defendant who has obtained a reversal of his conviction. Judge Kaufman characterizes the prosecutor's reduction in the charge at the bargaining stage as "consideration" for the defendant's plea of guilty. ${ }^{34}$ Furthermore he construes the defendant's successful appeal as a revocation of the bargain. ${ }^{35} \mathrm{He}$ concludes that the prosecutor's withdrawal of consent to the reduced charge does not evince vindictiveness, but rather it is a faultlessly rational response to the defendant's revocation of the bargain. $^{36}$ In effect, the defendant's successful appeal constitutes

higher charge or from the judge's imposing a higher sentence after retrial on the same charge. The deterrent effect of systematically imposing harsher sentences on successful appellants who are convicted at retrial is dramatically evident in the following letter sent by a prisoner to the judge who presided at his trial:

"Dear Sir:

'I am in the Mecklenburg County jail. Mr. —— chose to re-try me as I knew he would.

"Sir the other defendant in this case was set free after serving 15 months of his sentence, $I$ have served 34 months aud now $I$ am to be tried again and with all probility $I$ will receive a heavier sentence then before as you know sir my seutence at the first trile was 20 to 30 years. I know it is usuelly the courts prosedure to give a larger sentence when a new trile is granted I guess this is to discourage Petitioners.

"Your Honor, I don't want a new trile I am afraid of more time . . . .

"Your Honor, I know you liave tried to help me and God knows I appreceate this but please sir don't let the state retry me if there is any way you can prevent it."

"Very truly yours,"

North Carolina v. Pearce, 395 U.S. 711, 725 n.20 (1969) citing from Patton v. State of North Carolina, 256 F. Supp. 225, 231 n.7 (W.D.N.C. 1966). The author of the letter associates the heavier sentence after retrial with the judge's discretion, but his fears would be unchanged if the pattern of increased sentencing were based on a prosecutorial practice of reindicting successful appellants on higher charges.

31. United States ex rel. Williams v. McMann, 436 F.2d 103, 105-06 (2d Cir. 1970), cert. denied, 402 U.S. 914 (1971); People v. Harper, 32 Mich. App. 73, 188 N.W.2d 254, 258 (1971) (by inplication). But cf. Sefcheck v. Brewer, 301 F. Supp. 793 (S.D. Iowa 1969).

32. United States ex rel. Williams v. McMann, 436 F.2d 103, 105-06 (2d Cir. 1970), cert. denied, 402 U.S. 914 (1971); People v. Harper, 32 Mich. App. 73, 188 N.W.2d 254, 257-58 (1971); In re Sutherland, 6 Cal. 3d 666, 671-72, 493 P.2d 857, 861, 100 Cal. Rptr. 129, 133 (1972) (by implication).

33. 436 F.2d 103 (2d Cir. 1970), cert. denied, 402 U.S. 914 (1971).

34. Id. at 106.

35. Id.

36. Id. 
grounds for rescinding the bargain and returning the parties to the status quo ante. ${ }^{37}$

The contract approach to the scope-of-reprosecution problem is appealing because it is simple and couched in the familiar, quid-proquo terms of contract law. But the allure of the contract theory camouflages its failure to take account of the vindictiveness problem and behes the adhesive nature of the bargain struck between the prosecutor and the defendant.

The contract approach avoids rather than resolves the vindictiveness problem because it fails to anticipate that a prosecutor who reindicts on the higher charges can simultaneously be motivated by his behief that the plea-bargain contract has been rescinded and his desire to retaliate against defendants who succeed in appealing from pleabargain convictions. ${ }^{38}$ The reasoning of United States ex rel. Williams v. $M c M a n n^{39}$ assumes that the defendant's revoking the plea bargain by appealing the conviction precludes vindictiveness as a factor in the prosecutor's decision to reindict. But no more exalted an authority than common sense supports the proposition that the prosecutor's claim of release from the original bargain is compatible with his desire to retaliate against the defendant for having won an appeal. ${ }^{40}$ Such duality is particularly likely where the appeal succeeded on the ground that the prosecutor had improperly obtained the guilty plea. ${ }^{41}$

If it be conceded that the contract theory does not preempt the possibility of prosecutorial vindictiveness, then a court must still press the inquiry into whether vindictiveness played any part in the prosecutor's decision to reindict on the higher charges and expose the defendant to the risk of harsher punishment. Conscious of the extreme difficulty of affirmatively proving vindictive motive, the Court in North Carolina v. Pearce ${ }^{42}$ shifted the burden of proof to the government and specifically limited the type of evidence that could be presented

37. Id. See also In re Sutherland, 6 Cal. 3d 666, 672, 493 P.2d 857, 861, 100 Cal. Rptr. 129, 133 (1972).

38. Justice Stewart makes this point in a footnote to his dissenting opinion in Chaffin v. Stynchcombe, 412 U.S. 17 (1973):

The Court finds the possibility of prosecutorial malice "remote". Ante at 27 . The only basis for that conclusion appears to be that the prosecutor may have quite innocent strategic reasous for requesting an increased sentence after a retrial. But that does not foreclose the possibility that a prosecuor might have quite vindictive reasons for seeking a more severe penalty, and it underlines the extraordinary difficulty a defendant would have in attempting to prove a retaliatory motivation.

Id. at 36* (einphasis added).

39. 436 F.2d 103 (2d Cir. 1970), cert. denied, 402 U.S. 914 (1971).

40. See note 38 supra.

41. See Chaffin v. Stynchcounbe, 412 U.S. 17, 35-38 (1973) (Stewart, J., dissenting).

42. 395 U.S. 711 (1969). 
to overcome the presumption of judicial vindictiveness. The Court stated that only "identifiable conduct on the part of the defendant $o c$ curring after the time of the original sentencing proceeding"43 would be material to disprove vindictiveness. ${ }^{44}$ Applying this test to the prosecutor who reindicts on the higher charges without citing conduct of the defendant after sentencing as justification necessarily leads to the conclusion that the prosecutor has failed to rebut the presumption of retailiatory motive

A prosecutor might argue that the defendant's taking an appeal in violation of an express ${ }^{45}$ or implied term of the plea bargain constitutes conduct following sentencing which justifies reindictment on the higher charges. Pearce itself convincingly rebuts such an argument. Presumably, the Court in Pearce was indicating that it might tolerate a harsher sentence following retrial where the defendant had behaved in a violent, disruptive, or criminal manner since the time of his original sentencing. ${ }^{46}$ If taking an appeal, by itself, was the type of conduct contemplated by the Court in Pearce as a proper basis for an increased sentence after retrial, then the Court should have upheld the heavier sentence inposed on Rice, an apparent plea-bargain appellant himself. ${ }^{47}$ Therefore poimting to the defendant's appeal as objectionable conduct on the part of a plea-bargain appellant is not supported by Pearce. ${ }^{48}$ At best, identifying the defendant's appeal as objectionable

43. Id. at 726 (emphasis added).

44. Id.

45. See authorities cited in note 58 infra.

46. North Carolina v. Pearce, 395 U.S. 711, 726 (1969). But cf. United States v. Walker, 346 F.2d 428 (4th Cir. 1965).

47. See note 16 supra.

48. The distinction between plea-bargain appellants and appellants who contested their guilt at the original trial would be a relevant consideration under the "some valid motive" test formulated in United States ex rel. Williams v. McMann, 436 F.2d 103, 105 (2d Cir. 1970), cert. denied, 402 U.S. 914 (1971). See note 26 supra. But where the test is the absence of vindictive motive and the only basis for rebutting the presumption of vindictiveness is limited to conduct occurring after the original sentencing, the defendant's conduct before sentencing (i.e., his decision to plead guilty or not guilty) is wholly irrelevant to characterizing the conduct upon which the judge can properly rely to increase the appellant's punishment at retrial. Therefore, under the Pearce rule, an appeal by a plea-bargain defeudant, like an appeal by a defendant convicted at trial, is not conduct which dispels the presumption of vindictiveness which arises froin imposing harsher punishment on the successful appellant at retrial.

Perhaps the state would claim that characterizing the plea-bargain defendant's taking an appeal as objectionable conduct is justified because of the state's interest in expediting the administration of criminal justice by deterring appeals from plea bargains. This line of argumeut suggests the need for a balancing of interests analysis. The Court's silence in Pearce on balancing of interests can be interpreted to signify its behef that the state's showing of an interest in more efficient administration of criminal justice would not negate the unconstitutionality of vindictively notivated sentence in- 
conduct can be viewed as a reversion to the contract theory as a stratagem to evade a conclusive determination on the issue of vindictiveness.

\section{B. Contract of Adhesion}

Even if courts continue to embrace the contract analogy as the justification for terminating further inquiry into the possibility of prosecutorial vindictiveness, the approach inust be refined to imcorporate the contract doctrines which are most appropriate for analyzing the relationship between the prosecutor and the defendant. The conventional approach, as exemplified in United States ex rel. Williams $v$. McMann, ${ }^{49}$ treats a plea bargain like an ordinary contract between two equal parties bargaining at arm's length. When one of the parties revokes the contract, the other is entitled to be released from his obligation, and both parties are returned to the status quo ante. But the apparent symmetry of this simplistic model needs revision if the circumstances for negotiating the bargain and the terms of the agreement suggest the existence of a contract of adhesion.

Contracts of adhesion have generally been described as contracts forned by parties in grossly unequal bargaining positions. Typically the weaker party agrees to unfair or disadvantageous terms as a consequence of his feeble bargaining stance. ${ }^{50}$ The defendant who negotiates a guilty plea epitomizes the weaker party to a contract of adhesion. Unlike the normal party to a contract the defendant does not appear voluntarily in the prosecutor's office to negotiate a deal. $\mathrm{He}$ appears because he has been indicted, and he fears maximum pumishment will follow from a jury verdict against him. ${ }^{51}$ As evidence of his captive status he has already been obliged to remain in jail or post bail to ensure his attendance at trial.

Not only is the bargaining limited by the defendant's lack of leverage, but the substantive terms discussed during the actual plea bargaining are narrowly circumscribed by legislative inandate. The prosecutor

creases for successful appellants. However, the state's interest in efficiency is a legitimate one, and the weight it should be given in the context of reindicting successful plea-bargain appellants will be assessed in the equal protection section of this Comment. See text accompanying notes 126-179 infra.

49. 436 F.2d 103, 105-06 (2d Cir. 1970), cert. denied, 402 U.S. 914 (1971).

50. Henningsen v. Bloomfield Motors, Inc., 32 N.J. 358, 161 A.2d 69 (1960). See generally Wilson, Freedom of Contracts and Adhesion Contracts, 14 INT'L \& CoMP. L.Q. 172 (1965); Ehrenzweig, Adhesion Contracts in the Conflict of Laws, 53 Colum. L. Rev. 1072 (1953); Kessler, Contracts of Adhesion-Some Thoughts About Freedom of Contract, 43 Colum. L. Rev. 629 (1943).

51. See, e.g., Brady v. United States, 397 U.S. 742, 750-51 (1970). Statistics confirm the validity of the defendant's fear. See ADMINISTRATIve OFFICE OF THE United States Courts, Federal Offenders in the United States District Courts 57 (1971). 
trades on specific penalty schemes that the legislature has established for the offense or offenses charged and related offenses. ${ }^{52}$ The accused cannot effectively propose that the penalty schemes of other jurisdictions be used as the basis for an agreement, and he is not free to seek out another prosecutor who might offer a more generous bargain. The ceiling on the sentence a convicted defendant might be obliged to serve is fixed at the maximum penalty the legislature has prescribed for the offense or offenses charged. However, even the floor, that is the degree of leniency, is largely predetermined. According to Donald Newman, author of the leading empirical study on plea bargaining, plea bargains should not generally be viewed as individualized grants of exceptional leniency. ${ }^{53}$ Rather similar charge and sentence concessions are made to all defendants accused of similar crimes. ${ }^{54}$ Newman notes that attorneys rely primarily on precedents created by the "pattern of charge reduction which has developed in the jurisdiction" when arguing on behalf of plea-bargain defendants. ${ }^{55}$ To the extent plea-bargaining concessions reflect standarized practices and reliance on institutional precedent, the defendant is faced with a "take it or leave it" proposition in the classic tradition of adhesion contracts. ${ }^{50}$

In sum, the defendant inust negotiate the loss of his personal liberty in a coercive environment, motivated by fear of receiving maxiinum punishment at the hands of a jury, and intimidated by the array of enforcement powers available to the police, the prosecutor, and the judge. ${ }^{57}$ It is in this setting that the defendant and the prosecutor arrive at a plea bargain which includes the express ${ }^{58}$ or implied condition that the defendant will not seek an appeal fron his conviction. Such a condition requires the defendant to forego any correction of

52. But cf. People v. Foster, 19 N.Y.2d 150, 225 N.E.2d 200 (1967), where the appellate court upheld a guilty plea to the nonexistent offense of "attempted manslaughter in the second degree."

53. D. Newman, Convictions, The Determination of Guilt or Innocence Without Trial 213 (1966) [heremafter cited as Newman].

54. Id. at 230. Variations in plea bargains among like offenders do exist. But Newman attributes most of the variation to defendants' unequal opportunitites to retain counsel.

55. Id. at 213.

56. Henningsen v. Bloomfield Motors, Inc., 32 N.J. 358, 389-91, 161 A.2d 69, 86-87 (1960); Wilson, supra note 50, at 174-75; Ehrenzweig, supra note 50 at 1075, 1089; Kessler, supra note 50, at 632.

57. Cf. Miranda v. Arizona, 384 U.S. 436, 448-58 (1966).

58. Worcester v. Commissioner of Internal Revenue, 370 F.2d 713, 718 (1st Cir. 1966). Alabama and Mississippi mandate by statute that the guilty plea defendant waive his right of appeal. Code of AlabaMa tit. 15, $\$ 266$ (1958); Miss. Code ANN. tit. 99-35-101 (1972). Oregon restricts the guilty plea defendant's right of appeal to the grounds of excessive sentence or cruel and unusual punishment. ORE. REv. STAT. $§ 138.050$ (1967). 
prosecutorial impropriety as the price of retaining the benefit of any charge dismissal or reduction. ${ }^{59}$

A distinctive feature of the judicial attitude toward adhesion contracts generally is the courts' readiness to invalidate such contracts on the ground that they contravene public policy. ${ }^{60}$ The requirement that the defendant waive his statutory right of appeal to obtain a plea bargain contravenes public policy in several ways. First, the defendant is being asked to waive a right at a time when he is not in a position to assess the value of that right to him. He nnay be able to estimate roughly his odds at trial, ${ }^{61}$ but the ordinary plea-bargain defendant has no way to ascertain whether the prosecutor or judge has committed reversible error. ${ }^{82}$ Waiver of a right of unknown value undermines the constitutional policy of ensuring that a guilty plea is made voluntarily and with full knowledge of the consequences. ${ }^{03}$

Second, to justify breach of the "no appeal" condition as grounds for revoking the contract and returning the parties to the status quo ante the court must transform brimging a ineritorious appeal into a type of wrongful conduct which warrants subjecting the defendant to the risk of greater punishment. Ironically this transformation renders wrongful precisely that conduct which Pearce sought to insulate from judicial vindictiveness. ${ }^{64}$ Furthermore, this anomalous response to the pursuit of a legal right will engender cymicism among convicts and

59. Worcester v. Commissioner of Internal Revenue, 370 F.2d 713, 718 (1st Cir. 1966); Patton v. State of North Carolina, 381 F.2d 636, 639-40 (4th Cir. 1967), cert. denied, 390 U.S. 905 (1968).

60. See, e.g., Henningsen v. Bloomfield Motors, Inc., 32 N.J. 358, 386-404, 161 A.2d 69, 85-95 (1960).

61. Brady v. United States, 397 U.S. 742, 750 (1970).

62. See Newnan's comment on the dismayed state of mind of "less experienced and unrepresented defendants" at guilty plea proceedings. NEWMaAN, supra note 53, at 45-46. Also consider the likelihood that a defendant would be acquainted with the intricacies of the constitutional definition of "voluntariness" [e.g., McMann v. Richardson, 397 U.S. 759 (1970)] or the details of the procedural prophylactics required by the Constitution [e.g., Boykin v. Alabama, 395 U.S. 238 (1969)].

63. Boykin v. Alabama, 395 U.S. 238 (1969); Brady v. United States, 397 U.S. 742, 748 (1970); McCarthy v. United States, 394 U.S. 459 (1969); AMERICAN Bar Association, Project on Minnmum Standards for Crmminal Justice, Standards Relatting to Pleas of GuiLTy, §§ 1.3-1.8, at 22-36 (1967) thereinafter cited as ABA STANDARDS (1967)]; NEWMAN, supra note 53, at 10-50, 200-223.

64. In Green v. United States, 355 U.S. 184, 193 (1957), this effect was described by the Supreme Court as an "incredible dilemma" in which the law should not and does not place a defendant. This characterization of the defendant's choices arose in a double jeopardy context, bnt at least one prominent commentator has forcefully argued that Green should be interpreted as a due process question of access to post-conviction relief. Van Alstyne, supra note 8, at 630-32. Accord, North Carolina v. Pearce, 395 U.S. 711, 746 (1969) (Harlan, J., concurring in part and dissenting in part). 
compound the difficulty of rehabilitating them to respect the law. ${ }^{65}$

Third, and most important, the "no appeal" condition affords the prosecutor greater opportunity to abuse his discretionary charging power by substantially diminishing the possibility that his improper conduct will be publicized and condemned in a postconviction proceeding. An overbearing prosecutor who fears reversal might be especially tempted to impress on the defendant the threat of reindictment on the origimal, higher charges in the event of successful appeal. The potential for abuse of prosecutorial power is a particularly weighty consideration in light of the fact that the overwhelming majority of criminal defendants are convicted as the result of guilty pleas. ${ }^{86}$

These various compromises of public policy, coupled with the manifestly adhesive quality of the contract between the prosecutor and the defendant, argue for the invalidation of an express or implied "no appeal" condition attached to a plea bargain. By so invalidating the "no appeal" condition, the court would deprive the prosecutor of the argument that his right to a contract remedy overcomes the presumption of vindictiveness arising from his remdictunent of the defendant on the higher charges.

The practical consequence of this nodified importation of contract theory would be to limit the scope of reprosecution to the pleabargain conviction, unless evidence were presented of antisocial conduct subsequent to the original sentencing which justified reindictment on the liigher charges. This solution preserves society's interest in an opportunity to punish criminals ${ }^{67}$ while serving the three public policy goals of ensuring voluntary and intelligent guilty pleas, proinoting respect for the law among convicts in the process of rehabilitation, and maintaining appellate review as a sanction against the misuse of prosecutorial power.

This section has focused on the analogies between judicial and prosecutorial vindictiveness, and contracts of adhesion and the plea-bargain "contract" to illuminate the due process limitations on the scope of reprosecution. While these analogies are instructive, the scope-of-

65. Cf. Newman, supra note 53, at 45-46. See also North Carolina v. Pearce, 395 U.S. 711, 738 (1969) (Black, J., concurring in part and dissenting in part).

66. See note 1 supra.

67. Given that the great majority of defendants are convicted as a consequence of plea bargains [See note 1 supra] and that similar plea bargains are commonly offered to all defendants accused of the same offense [see text accompanying note 54 supra], the reality is that the plea-bargain punishment is the usual punishinent meted out for any particular type of crime. Therefore, limiting the scope of reprosecution to the original conviction is equivalent to limiting the potential punishment for reconviction to the punishment ordinarily imposed for that offense. Cf. Stroud v. United States, 251 U.S. 15 (1919); United States v, Tateo, 377 U.S. 463 (1964). 
reprosecution issue is most commonly aired as a double jeopardy controversy. The viability of that approach will be examined in the next section.

\section{III}

\section{DOUBLE JEOPARDY}

In Mullreed v. Kropp ${ }^{68}$ the Sixth Circuit faced the issue of the permissible scope of reprosecution following a successful collateral attack on a plea-bargain conviction. As the basis of its holding limiting the scope of reprosecution to the offense for which the defendant was originally convicted, the court relied on the double jeopardy clause of the fifth amendment as incorporated by the fourteenth amendment and applied to the states. ${ }^{69}$ The court expanded the implied acquittal concept of Green v. United States ${ }^{i 0}$ to spare Mullreed from reprosecution on the higher cliarge. Content with this extrapolation from establislied double jeopardy doctrine, the court deliberately chose to ignore the threshold question of whether jeopardy ever attached on the original, higher offense. ${ }^{71}$ As will be shown in detail, Mullreed illustrates the general inadequacy of the double jeopardy clause as a doctrinal framework for resolving the scope-of-reprosecution problem.

\section{A. Implied Acquittal?}

In Mullreed v. Kropp ${ }^{72}$ the two defendants, Passow and Mullreed, stole $\$ 40$ from a tavern, and in so doing, struck the bar attendant with a clrair. They were charged with armed robbery and the lesserincluded offense of unarmed robbery. The district attorney induced the defendants to plead guilty to the lesser offense by informing thein that there would be no jury in the county for three months, that without bail money they would spend the three months in jail, and that at the end of that time they would be prosecuted on both the armed and unarmed robbery counts. Before the scheduled submission of the guilty pleas, Passow withdrew froin the bargain. He went before a different judge than Mullreed and received a sixty-day sentence. Mullreed asked for the assistance of counsel on the armed robbery charge at his arraignment. The judge considered but did not grant the request.

68. 425 F.2d 1095 (6th Cir. 1970); contra Ward v. Page, 424 F.2d 491 (10th Cir. 1970), cert. denied, 400 U.S. 917 (1970); People v. Harper, 32 Mich. App. 73, 188 N.W.2d 254 (1971).

69. Benton v. Maryland, 395 U.S. 784, 794-96 (1969), established the proposition that the federal standard of double jeopardy expressed in the fifth amendment is incorporated by the fourteenth amendment and applicable to the states.

70. 355 U.S. 184,190 (1957).

71. Mullreed v. Kropp, 425 F.2d 1095, 1099 n.4 (6th Cir. 1970).

72. Id. 
Nevertheless Mullreed adhered to his bargain and pleaded guilty to the lesser-included offense of unarmed robbery. The court accepted Mullreed's plea and sentenced him to a ten-to-fifteen-year prison term.

Mullreed collaterally attacked his conviction in federal court and won reversal on the ground that he had been unconstitutionally denied his right to counsel. ${ }^{73}$ Reindicted for armed robbery, he was tried and convicted by a jury and sentenced to serve fifteen to thirty years. Eleven years after his original conviction, Mullreed once again attempted to attack his conviction collaterally in the federal courts, but the district court denied relief. ${ }^{74}$ Mullreed appealed and thereby directly confronted the Sixth Circuit with the scope of reprosecution issue.

The implied-acquittal concept, the basis of the Sixth Circuit's response to Mullreed's claim, was first approved by the Suprente Court in Green v. United States. ${ }^{75}$ Green was tried on charges of first degree nrurder and arson. The jury, acting in accordance with the judge's instructions, returned guilty verdicts for second degree nururder and arson without inaking any comment on the first degree nuurder charge. On appeal, Green won a new trial on the ground that the judge had given erroneous instructions to the jury. ${ }^{76}$ The prosecutor thereupon reindicted Green for first degree inurder and obtained a jury conviction. The judge sentenced Green to death.

Green appealed froin this conviction on the theory that he had been subjected to double jeopardy. The Supreme Court held that with respect to the first degree nuurder charge, the government had violated the double jeopardy prohibition. To achieve this result the Court construed the original jury's silence on the first degree nuurder charge as an implied acquittal:

At Green's first trial the jury was authorized to find him guilty of either first degree murder . . . or, alternatively of second degree murder....

Green was in direct peril of being convicted and punished for first degree murder at his first trial. He was forced to run the gantlet once on that charge and the jury refused to convict him.

73. Mullreed v. Bannan, 137 F. Supp. 533 (E.D. Mich. 1956).

74. Mullreed v. Kropp, 425 F.2d 1094, 1097 (6th Cir. 1970).

75. 355 U.S. 184 (1957). Accord, Price v. Georgia, 398 U.S. 323, 328-29 (1970).

76. Green v. United States, 218 F.2d 856 (D.C. Cir. 1955). The circuit court pointed out that Washington, D.C. was a felony murder jurisdiction. Therefore, the judge could not properly instruct the jury that it would be possible to find Green guilty of the felony of arson and limit the murder conviction to second degree murder. The felony nurder rule makes any killing which the defendant commits in the course of the felony first degree murder. A jury that considers such a charge can only acquit or convict of murder in the first degree. 
When given the choice between finding him guilty of either first or second degree inurder, it chose the latter. In this situation the great majority of cases in this country have regarded the jury's verdict as an implicit acquittal on the charge of first degree murder. ${ }^{77}$

This language stresses the significance of the choice open to the jury, after hearing all the evidence, to convict of first degree murder. ${ }^{78}$

Having found an implied acquittal in the jury's refusal to convict, the Court invoked the well established double jeopardy rule which prohibits reprosecution on the same charges of which the defendant has been acquitted. ${ }^{79}$ This rule reflects the strong double jeopardy policy against requiring the defendant to run the "gantlet" more than once. ${ }^{80}$ Accordingly, the Court invalidated Green's second trial for first degree murder and laid down the rule limiting the scope of reprosecution in similar situations. ${ }^{81}$

Chief Judge Phillips of the Sixth Circuit strained to mold the implied-acquittal concept of Green to the contours of the plea-bargain situation in Mullreed v. Kropp. ${ }^{82}$ He drew an analogy between the fact-finding function of the jury and the trial judge's obligation to determine if a factual basis exists for the plea. ${ }^{83}$ The trial judge's silence on the armed robbery count was treated as the functional equivalent of the jury's silence on the first degree murder charge in Green. The court's observation that the statutory definitions of armed and unarmed robbery contain contradictory elements bolstered the analogy. ${ }^{84}$ According to Judge Phillips, it would be impossible for the trial judge to have found facts which supported the guilty plea to unarmed robbery without having ruled out the possibility that the defendant had coinmitted arined robbery. ${ }^{85}$ Having shaped the trial judge's guilty plea determination into an implied acquittal, the court apphed the double jeopardy clause to bar reprosecution. ${ }^{86}$

77. Green v. United States, 355 U.S. 184, 189-90 (1957).

78. Id. at 191.

79. United States v. Ball, 163 U.S. 662 (1895) and Kepner v. United States, 195 U.S. 100 (1904) are the leading cases. Accord, Fong Foo v. United States, 369 U.S. 141 (1962) (per curiam). As a result of Benton v. Maryland, 395 U.S. 784 (1969) the absolute double jeopardy bar following acquittal applies to all the states through the due process clause of the fourteenth amendment.

80. Id. The strength of this policy is particularly evident in Kepner v. United States, 195 U.S. 100 (1904), where the Supreme Court held that even though the government may be able to demonstrate that its case failed because of prejudicial error in the conduct of the original proceedings, the government is absolutely forbidden to take an appeal from a prior acquittal.

81. Green v. United States, 355 U.S. 184, 190-91 (1957).

82. 425 F.2d 1095 (6th Cir. 1970).

83. Id. at $1100-01$.

84. Id. at 1102 .

85. Id.

86. Id. at 1101-02. 
In light of the gross disparity in the punishments meted out to Mullreed and Passow, and the serious error committed by the judge in denying Mullreed counsel, the result is laudable as a display of humamitarian ingenuity. But the analogy used to rationalize the decision is fatally flawed as a legal analysis. ${ }^{87}$ The fact-finding done by a judge or jury in a complete criminal trial and that done by a judge accepting a guilty plea are quite different processes which serve overlapping, but basically distinct purposes. In a trial both the criminal defendant and the state have had a substantial period of time to develop evidence and prepare their cases. The evidence is presented to the judge or jury in a full-scale adversary setting where witnesses are carefully crossexamined and the probative value of all the evidence is vigorously questioned by counsel on both sides. In contrast, the guilty-plea proceeding is a summary affair which usually takes place at a time when the state has made only a preliminary investigation, and the defendant often has had no opportunity to gather evidence in his favor. Because the defendant has agreed to the plea, he ordinarily does not seek to cross-examine witnesses or challenge other evidence offered by the prosecutor.

The characteristic function of the judge or jury hearing evidence at trial is to determine exactly what happened and whether the defendant's conduct supports any of the charges against him. As stated by the nuajority in Green, the jury has the option to convict on the highest charge in the indictment or any lesser-mcluded offense. ${ }^{88}$ Given the breadth of the judge's or jury's fact-finding responsibility and the nature of a trial, an appellate court can reasonably infer that the judge's or the jury's refusal to convict of a particular charge is an acquittal for the purposes of double jeopardy. ${ }^{89}$

87. In Ward v. Page, 424 F.2d 491, 493 (10th Cir. 1970), cert. denied, 400 U.S. 917 (1970), the Tenth Circuit implicitly recognized the defects in Mullreed by refusing to extend the double jeopardy implications of a jury verdict to convictions based on guilty pleas.

88. Green v. United States, 355 U.S. 184, 189-90 (1957).

89. Led by Justice Frankfurter, the dissenters in Green v. United States, 355 U.S. 184, 214-16 (1957) challenged the rationality of using the notion of an implied acquittal as the touchstone for the application of double jeopardy. See Van Alstyne, supra note 8, at 631-632; Note, Constitutional Law-Former Jeopardy-Retrial for Greater Offense After Conviction of Lesser Included Offense Reversed On Appeal, 56 MrCH. L. Rev. 1192 (1958); Note, Criminal Law: Double Jeopardy: Limited Waiver, 6 U.C.L.A. L. REv. 321, 322-23 (1959). Justice Frankfurter noted that the appeal only succeeded because the judge's instructions had permitted the jury to return a verdict which was legally inconsistent with the jury's factual findings. The jury found that the defendant had committed arson and second degree inurder. If the jury had been properly instructed, it would have had no logical choice but to acquit or return a conviction of first degree murder. See note 76 supra.

The majority, on the other liand, recognized that double jeopardy protection is not intended to distinguish between logical and illogical acquittals. Rather the double 
The judge's fact-finding function at guilty-plea proceedings is quantitatively and qualitatively more limited. He does not seek to determine if the defendant has committed acts which would justify conviction of every charge included in the indictment. ${ }^{30}$ Rather he undertakes a factual inquiry to determine if the plea was given voluntarily and knowingly, ${ }^{01}$ and establishes a record on those issues for purposes of appellate review..$^{92}$ Generally a court is satisfied if the defendant has committed the crime to which he is pleading guilty or some related

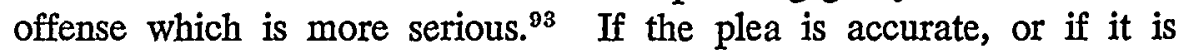
inaccurate but based on facts which would support conviction on a higher, related offense, the probability that it is being made voluntarily is considerably enhanced..$^{.4}$

jeopardy clause guarantees that the defendant should only have "to run the gantlet" once for a particular offeuse:

The underlying idea is . . . that the State with all its resources and power should not be allowed to make repeated attempts to convict an individual for an alleged offense, thereby subjecting him to embarrassment, expense, and ordeal and compelling him to live in a continuing state of anxiety and insecurity ...

Green v. United States, 355 U.S. at 187. Thus the issue at stake for double jeopardy purposes is uot the logical correctness of the acquittal, but whether the defendant has already once withstood the rigors of being tried and placed in peril of conviction on the charge. In Green, the prosecutor preseuted his proof at trial, and the jury refused to convict on the charge of first degree murder. Certainly this constituted forcing tho defendant "to run the gantlet." Therefore, with respect to double jeopardy, the majority treated the jury's refusal to acquit the defendant of first degree murder as fully equivalent to an express acquittal of that offense.

90. See FED. R. CRIM. P. 11. The Advisory Committee's commentary on the 1966 amendments to Rule 11 states that:

The court should satisfy itself, by inquiry of the defendant or the attorney for the government, or by examining the presentence report, or otherwise, that the conduct which the defendant admits constitutes the offense charged in the indictunent or information or an offense included therein to which the defendant has pleaded guilty. (Emphasis added.)

The alternative of accepting the plea to a lesser offense relieves the judge of any obligation to consider the facts presented at the time of the plea in relation to the highest charge in the indictment. See also ABA Standards 1967, supra note 63, $\S 1.8$, at 36-48.

91. Brady v. United States, 397 U.S. 742, 748 (1969). See Newman, supra note 53, at 10-12; ABA STANDARDS 1967, supra note 63, $\$ \$ 1.5 \& 1.6$, at 29-34.

92. See cases cited in note 96 infra; ABA Standards 1967, supra note 63, \$ 1.7, at 34-36; NewMAN, supra note 53, at 218-23.

93. See note 90 supra. See Brady v. United States, 397 U.S. 742, 751 (1969). See generally NeWMAN, supra note 53, at 67-130, 173-87.

94. Of course, where the plea is more serious than any conduct the defendant has admitted, the court would rightfully suspect the voluntariness of the plea and refuse to accept it. ABA STANDARDS 1967 , supra note $63, \S 1.6$, at 30-32; Fed. R. CRIM. P. 11. Similarly where the facts elicited from the defendant do not correspond to the offense charged in the indictinent or any lesser, related offense admitted in the guilty plea, the judge might properly draw the conclusion that the defendant did not fully understand the consequences of his plea. People v. Burt, 29 Mich. App. 275, 185 N.W.2d 207, 208 (1970); ABA Standards 1967, supra note 63, § 1.6, at 30-32; Fed. R. CRIM. P. 11. 
The judge's interest in creating an adequate record of the factual basis for the plea is also tied directly to the issue of voluntariness. A guilty plea involves the waiver of several constitutional rights including the right to jury trial, the right to confront witnesses, and the privilege against self-incrimination. ${ }^{95}$ The Supreme Court has concluded that an affirmative record of guilty-plea proceedings is a prerequisite for meaningful review of a postconviction challenge to the voluntariness of a guilty plea. ${ }^{96}$ Since noncompliance with this requirement will result in reversal, ${ }^{97}$ trial judges have a major incentive to lay on the record the essential facts which support the plea.

The judge's responsibility to find voluntariness and to establish a record supporting that finding invite him to focus on whether the defendant is pleading to an unnecessarily grave offense. This effort to protect the defendant from overcharging naturally diverts the judge from scrutinizing the factual basis of the plea to determine the maximum conviction that could be obtained. A simple hypothetical will suffice to illustrate the point: a man kills his wife several hours after learning that she has been unfaithful to him. After being indicted for first degree murder, he is before the judge pleading guilty to voluntary manslaughter pursuant to a plea bargain arranged by his lawyer and the district attorney. The judge is not likely to probe for evidence of premeditation to support a first degree murder conviction where a factual determination supporting voluntary manslaughter, a lesser-included offense, will satisfy any appellate imquiry into the possibility of inflated charges vitiating the voluntariness of the plea.

The narrower scope of the judge's fact-finding function tends to leave unresolved the question of acquittal on the higher charge. As a consequence, most courts will resist applying the Green concept of implied acquittal to the plea-bargain defendant and affording such defendants double jeopardy protection from reprosecution on the original, higher charges. ${ }^{98}$

\section{B. Attaching of Jeopardy?}

The Mullreed court's reliance on double jeopardy analysis is further weakened by the court's failure to face squarely the question of whether jeopardy ever attached on the original, higher charge. ${ }^{99} \mathrm{Re}-$ prosecution is not prohibited in all cases where jeopardy has at-

95. Boykin v. Alabama, 395 U.S. 238, 243 (1969).

96. Id.; McCarthy v. United States, 394 U.S. 459 (1969); People v. West, 3 Cal. 3d 595, 608-11, 477 P.2d 409, 417-18, 91 Cal. Rptr. 385, 393-95 (1970).

97. Boykin v. Alabama, 395 U.S. 238 (1969).

98. E.g., Ward v. Page, 424 F.2d 491 (10th Cir. 1970), cert. denied, 400 U.S. 917 (1970).

99. Mullreed v. Kropp, 425 F.2d 1095, 1099 n.4 (6th Cir. 1970). 
tached, ${ }^{100}$ but the double jeopardy bar is unavailable where jeopardy has not attached. ${ }^{101}$

A determination that jeopardy has attached requires that the prosecutor either go forward or bear the risk that double jeopardy will bar reprosecution for the same offense. ${ }^{102}$ In jury trials, jeopardy for the charge attaches when the jury is impaneled. ${ }^{103}$ In a trial without a jury, jeopardy attaches when the judge begins to hear the evidence. ${ }^{104}$ Both these rules, however, are qualified by the holding of United States $v$. Ewell ${ }^{105}$ that the attaching of jeopardy on one offense does not preclude subsequent indictment for a different offense arising froin the same factual transaction.

Because it disposed of the scope of reprosecution problem on the grounds of imphed acquittal, the court in Mullreed ostensibly declined to consider whether jeopardy had attached on the armed robbery count. ${ }^{106}$ Yet in the text of the opimion, the court seeined to lay the groundwork for overcoming a no-attaching-of-jeopardy attack on its reasoning. The court belabored the poimt that the judge had conducted an evidentiary hearing on the question of the defendant's guilt. ${ }^{107}$ Presumably Judge Phillips would infer that the evidentiary hearing at the time of the submission of the guilty plea satisfies the hearing-of-the-evidence test for the attaching of jeopardy in a nonjury proceeding. The defect in this analysis is that the judge was not asked to consider the original, higher charge at the guilty-plea proceeding but only to find a factual basis for the unarmed robbery count. Furthermore, the law is clear that indictment and preliminary hearing do not cause jeopardy to attach. ${ }^{108}$ Thus, it may be argued that jeopardy never attached on the arined robbery count. And insofar as a court would view arned robbery as an offense separate and different from the lesser-included offense of unarmed robbery, the rule of United States v. Ewell ${ }^{109}$ would permit reindictment on the armed robbery

100. Compare Downum v. United States, 372 U.S. 734 (1963) (jeopardy attached, mistrial declared, reprosecution barred) with Illinois v. Somerville, 410 U.S. 458 (1973) (jeopardy attached, mistrial declared, reprosecution allowed). For a general discussion of this issue, see Note, Double Jeopardy: The Reprosecution Problem, 77 HARV. L. REv. 1272 (1964).

101. United States v. Ewell, 383 U.S. 116, 124-25 (1966).

102. United States v. Jorn, 400 U.S. 470 (1971); Downum v. United States, 372 U.S. 734 (1963).

103. Downum v. United States, 372 U.S. 734 (1963). Accord, United States v. Sisson, 399 U.S. 267, 305 (1970).

104. McCarthy v. Zerbst, 85 F.2d 640, 642 (10th Cir. 1936), cert. denied, 299

U.S. 610 (1936).

105. 383 U.S. 116, 124-25 (1966).

106. Mullreed v. Kropp, 425 F.2d 1095, 1099 n.4 (6th Cir. 1970).

107. Id. at 1100-01.

108. See cases cited in notes 103 and 104 supra.

109. 383 U.S. 116, 124-25 (1966). 
count without infringing Mullreed's right to double jeopardy protection.

The weaknesses of the Mullreed v. Kropp ${ }^{110}$ opinion are symptomatic of the shortcomings of double jeopardy as a doctrinal tool for evaluating the issues raised by the reprosecution of successful pleabargain appellants on the original, higher charges. The concepts of iniplied acquittal and attachment of jeopardy are drained of practical meaning where the defendant has not actually been compelled to "run the gantlet"111 or face the "peril of conviction"112 on the higher charge. In other words, agreeing to submit a guilty plea on a lesser charge displaces "running the gantlet" and eliminates the "peril of conviction" of the higher charge. As a result the policies of upholding the finality of an acquittal and demarcating the line where a prosecutor will be required to go forward with the state's case are not served. Given the inapplicability of these policies to the reprosecution of successful plea-bargain appellants on the higher charges, the use of double jeopardy will probably be rejected by all but the most solicitous of defendant-oriented courts. ${ }^{113}$

The inapplicability of double jeopardy doctrines does not absolve Mullreed of all its constitutional infirmities. The offense to due process has already been discussed, and the next section of this Comment will explore the equal protection implications of remdicting successful pleabargain appellants on the original, higher charges.

\section{III}

\section{Equal Protection}

Notwithstanding the extensive attention the Warren court devoted to the issue of access to postconviction remedies for indigents, ${ }^{114}$ courts faced with the scope of reprosecution issue and its implications for access to appeal by plea-bargain defendants ${ }^{115}$ liave tended to neglect

110. 425 F.2d 1095 (6th Cir. 1970).

111. Green v. United States, 355 U.S. 184, 190 (1957).

112. Id.

113. Compare United States ex rel. Williams v. McMann, 436 F.2d 103 (2d Cir. 1970), cert. denied, 402 U.S. 914 (1971) and Ward v. Page, 424 F.2d 491 (10th Cir. 1970), cert. denied, 400 U.S. 917 (1970) with Mullreed v. Kropp, 425 F.2d 1095 (6th Cir. 1970).

114. Rinaldi v. Yeager, 384 U.S. 305 (1966); Draper v. Washington, 372 U.S. 487 (1963); Lane v. Brown, 372 U.S. 477 (1963); Douglas v. California, 372 U.S. 353 (1963); Smith v. Bennett, 365 U.S. 708 (1961); Burns v. Ohio, 360 U.S. 252 (1959); Eskridge v. Washington State Bd. of Prison Ternıs and Paroles, 357 U.S. 214 (1958); Griffin v. Illinois, 351 U.S. 12 (1956).

115. Although statistics are not readily available on the point, it would seem reasonable to assume that a substantial proportion of plea bargain appellants are indigents. See NEWMaN, supra note 53, at 228. 
the equal protection approach. ${ }^{116}$ The Supreme Court mentioned equal protection in North Carolina $v$. Pearce ${ }^{117}$ where the issue was harsher punishment following an appeal and retrial on the same offense. In rather summary fashion, however, the Court concluded that because successful appellants might or might not be convicted on retrial, they could not be considered a similarly situated group for purposes of equal protection. ${ }^{118}$ The Court imphed that unless all successful appellants were certain to be convicted and suffer harsher punishment after retrial, they could not all be rationally classified as a similarly situated group. Although successful appellants subject to retrial cannot be classified together with respect to the certainty of harsher punishment, they surely can be rationally classified as a group which must risk the possibility of harsher punishment in order to obtain a new trial. ${ }^{119}$ By analogy, all successful appellants from convictions based on negotiated pleas to lesser imcluded offenses or reduced charges can be classified as a group which is exposed to the risk of increased punishment as a consequence of being reindicted on the origimal, higher charges. ${ }^{120}$ And unlike the decision as to whether the successful appellant is ultimately acquitted or reconvicted, a decision which depends on the particular merits of each case, the risk of increased punishment is imposed on all members of the group for the same reason-they succeeded in persuading an appellate court that they were the victims of prejudicial error at the time of their original conviction.

Identifying the classification made by the rule of law under attack is only the first step in equal protection analysis. ${ }^{121}$ The most critical, if not determinative, question is the standard of review that will be

116. But cf. Patton v. State of North Carolina, 381 F.2d 636, 641-43 (4th Cir. 1967), cert. denied, 390 U.S. 905 (1968).

117. 395 U.S. 711 (1969). But see Patton v. State of North Carolina, 381 F.2d 636, 641-43 (4th Cir. 1967), cert. denied, 390 U.S. 905 (1968).

118. Id. at 722-23.

119. Patton v. State of North Carolina, 381 F.2d 636, 643 (4th Cir. 1967), cert. denied, 390 U.S. 905 (1968).

120. Cf. id. The reader should note that this class of plea-bargain appellants excludes appellants from bargains based on a recommendation of sentence leniency because such bargains are not legally subject to reprosecution on charges higher than the origmal conviction. Cf. Sefcheck v. Brewer, 301 F. Supp. 793 (S.D. Iowa 1969). In light of North Carolina v. Pearce, 395 U.S. 711 (1969), the insulation of this group of plea-bargain appellants from the threat of reprosecution on the higher charges suggests a blatant violation of equal protection. See text accoinpanying notes 172-79 infra for development of this issue as an under-inclusiveness problem.

121. The class affected by the reprosecution rule could alternatively be defined more broadly to encompass all plea-bargain appellants. Patton v. State of North Carolina, 381 F.2d 636, 642 (4th Cir. 1967), cert. denied, 390 U.S. 905 (1968). Redefining the class more broadly does not materially change the equal protection analysis presented in this Part; but where modifications based on this broader class would be appropriate, they will be discussed in the notes. See notes 134,169 and 172 infra. 
used to test the constitutionality of the classification. ${ }^{122}$ This Comment discusses three standards of equal protection review. The first two, the "reasonableness" standard and the "strict scrutiny" standard, represent the two-tiered system that characterized the Warren Court era.123 The third standard, "intensified means scrutiny," 124 is an intermediate standard of review which Professor Gunther has identified as an emerging trend in recent Burger Court decisions. ${ }^{125}$ The only one of these standards of review which supports the equal protection validity of reprosecuting plea-bargain appellants on the original, higher charges is the reasonableness standard.

\section{A. Reasonableness}

The usual ground for upholding a statute or rule of law under the equal protection standard of reasonableness is the existence of any conceivable, legitimate purpose which is served by the statute or judicial rule in question. ${ }^{126}$ This test invites the court to speculate on whether any permissible interest of government might rationally be served by the law which is being challenged. Although the lack of judicial analysis of the scope of reprosecution problem as an equal protection issue has largely obscured the precise objectives sought by permitting reindictment on the higher charges, at least four objectives can be inferred from the existence of the rule. First is the government's interest in reducing the already heavy burden on appellate courts by discouraging frivolous appeals and collateral attacks. ${ }^{127}$ Second, the state has an interest in maintaining the effectiveness of plea bargains as a procedure for avoiding the expense of trials. ${ }^{128}$ Third, the government might assert an interest in preserving the deterrent effect

122. Jefferson v. Hackney, 406 U.S. 535, 576 (1972) (Marshall, J., dissenting). See generally Developments in the Law-Equal Protection, 82 HARv. L. Rkv. 1065, 1076-1132 (1969) [hereinafter cited as Developments].

123. Gunther, The Supreme Court 1971 Term, Foreword: In Search of Evolving Doctrine on a Changing Court: A Model for a Newer Equal Protection, 86 HARv. L. Rev. 1, 8 (1972) [hereinafter cited as Gunther]. For a useful and compact general discussion of the Warren court's approach to equal protection, see Developments, supra note 122.

124. Gunther, supra note 123 , at 20-24.

125. Id. at 24-48.

126. See, e.g., McGowan v. Maryland, 366 U.S. 420, 425-26 (1961).

127. See ABA Project on Minimum Standards for Criminal Justice, Standards Relating to Criminal Appeals 19-21 (Approved Draft 1969); Carrington, Crowded Dockets and the Courts of Appeals: The Threat to the Function of Review and the National Law, 82 HARv. L. REv. 542, 542-549 (1969). Presumably the government does not seek to reduce the appellate work load by eliminating meritorious appeals. See North Carolina v. Pearce, 395 U.S. 711, 739 (1969) (Black, J., concurring in part and dissenting in part); People v. Henderson, 60 Cal. 2d 482, 497, 386 P.2d 677, 686, 35 Cal. Rptr. 77, 86 (1963).

128. The Supreme Court, 1969 Term, 84 HARv. L. REv. 1, 150 (1970). 
of its discretionary power to reindict on the higher charges as a means of exposing defendants who stand trial to the maximun pumishment allowed under the law. Fourth, the state has an interest in retaining broad charging power as a tactical weapon to compensate for the possibility of a jury's returning a compromise verdict at retrial. ${ }^{120}$

Inasmuch as allowing reprosecution on the higher charges at retrial discourages appeals in general, ${ }^{130}$ such a rule will have the desired effect of deterring inany plea-bargain convicts froin pursuing frivolous appeals. ${ }^{131}$ Also inaking an unattractive example of appellants who deserve new trials serves the government's second interest, that is, minimizing the number of challenges to plea bargains resulting in new

129. Chaffin v. Stynchcombe, 412 U.S. 17, 27 n.13 (1973).

130. But cf. Chaffin v. Stynchcombe, 412 U.S. 17 (1973) where the majority reaches the conclusion that the risk of harsher punishment at retrial is not a significant deterrent to prospective criminal appellants. Id. at 32-35. The Court reasoned that so many uncertain contingencies (e.g., successful appeal, retrial, and reconviction) had to occur between the time defendants decided to appeal and the time at which they would be subject to a possibly higher sentence that a rule which permitted a jury to impose a harsher sentence following a successful appellant's retrial would not be a significant factor in discouraging appeals. Id. In view of the Court's express approval in Chaffin of North Carolina v. Pearce, 395 U.S. 711 (1969), this line of reasoning is remarkably illogical. In construing Pearce the Court stated that a policy of meting out higher sentences to successful appellants at retrial violates the Constitution not only because of the due process owing to the successful appellant, but also because "the wrong would extend as well to those who elect not to exercise their rights of appeal because of a legitimate fear of retaliation." Chaffin v. Stynchcombe, supra at 25. But the Court seems to forget that the same attenuated chain of contingent events must occur in the case of the appellant who suffers a harsher sentence vindictively imposed by a judge as in the case of the appellant who receives his harsher sentence from a jury. If the chain of contingencies does not dissipate the deterrent effect in the Pearce situation, then it logically cannot be said that the same set of contingent events renders the deterrent effect de minimis when the jury is the sentencing authority at the end of the process.

Furthermore, the Court seems to disregard the numerous authorities which recognize the broad deterrent significance of a procedural rule which subjects a defendant to the risk of more severe punishment as a consequence of winning an appeal, notwithstanding the intervening contingencies. See United States v. Ewell, 383 U.S. 116, 127-30 (1965) (Fortas, J., dissenting); Fay v. Noia, 372 U.S. 391, 440 (1963); Green v. United States, 355 U.S. 184, 191-92 (1957); United States ex rel. Williams v. McMann, 436 F.2d 103, 107 (2d Cir. 1970) (by implication), cert. denied, 402 U.S. 914 (1971); Mullreed v. Kropp, 425 F.2d 1095, 1102 (6th Cir. 1970) (by implication); Patton v. State of North Carolina, 381 F.2d 636, 639-40 (4th Cir. 1967), cert. denied, 390 U.S. 905 (1968); Marano v. United States, 374 F.2d 583, 585 (1st Cir. 1967); United States ex rel. Hetenyi v. Wilkins, 348 F.2d 844, 859 (2d Cir. 1965), cert. denied, 383 U.S. 913 (1966); United States v. Walker, 346 F.2d 428, 430 (4th Cir. 1965); Sefcheck v. Brewer, 301 F. Supp. 793, 795 (S.D. Iowa 1969). Secondary sources which analyze the risk of harsher punishment as a significant deterrent to prospective appellants include Van Alstyne, supra note 8, at 613-36, and Note, Another Look at Unconstitutional Conditions, 117 U. PA. L. REv. 144, 158-62 (1968).

131. See Note, Another Look at Unconstitutional Conditions, supra note 130, at $158-62$. 
trials. ${ }^{132}$ The difficulty with the rule permitting reprosecution on the higher charges is that the rule operates arbitrarily to promote the government's first and second interests. The sanction imposed by the rule is only applied against defendants who have brought successful and, we assume, meritorious, appeals. ${ }^{133}$ Thus, with respect to the gov. ernment's interest in discouraging frivolous appeals and minimizing new trials, the rule permitting reprosecution of successful plea-bargain appellants on the original, higher cliarges fails the reasonableness test. ${ }^{134}$

By definition, reprosecution on the higher charges authorizes the prosecutor to expose the defendant to the maximum punishment as a deterrent to crime. Preserving the power to reindict on the higher charges as a means of enforcing the legislature's intent to deter crime, the third interest, must also be rejected under the reasonableness standard. The individual who lias pleaded guilty to the crime has not been deterred. And the possibility that a potential criminal will consider a nuance of criminal procedure like the scope of reprosecution following appeal froin a plca bargain before committing an offense is virtually nonexistent. Moreover, the reality that the great majority of convicts serve sentences based on negotiated guilty pleas ${ }^{135}$ weakens the deterrence argument. If the plea-bargain charge and sentence is the norm, limiting the scope of reprosecution to the plea-bargain charge will not detract significantly from the role of punishment as a deterrent to crime. In light of the manifestly inconsequential character of the deterrence argument, further discussion of this interest will be omitted in the strict scrutiny and the intensified means scrutiny sections.

Also by definition, reprosecution on the higher charges allows the prosecutor to use the higher charge as a tactical weapon, the fourth interest. Pursuing this imterest by remdicting plea-bargain appellants is rational and permissible conduct by the prosecutor. ${ }^{136}$ Therefore,

132. See, e.g., United States ex rel. Williams v. McMann, 436 F.2d 103, 107 (2d Cir. 1970), cert. denied, 402 U.S. 914 (1971).

133. Cf. Patton v. State of North Carolina, 381 F.2d 636, 643 (4th Cir. 1967), cert. denied, 390 U.S. 905 (1968).

134. If the relevant class were defined more broadly to include all plea-bargain appellants, the rule of reindictment on the higher charges could not be dismissed as arbitrary under the reasonableness test. No doubt a certain proportion of plea-bargain appellants pursue frivolous postconviction claims, and they do not deserve a new trial. Therefore the rule does exhibit some rational basis as a means of effectuating the government's first and second interests with reference to this broader class. However, even when the broader definition of the affected class is used, the rule presents problems of overinclusiveness and underinclusiveness which offend the intensified means standard of equal protection. See text accompanying notes 168 to 179 and notes 169 and 172 infra.

135. See note 1 supra.

136. Cf. Chaffin v. Stynchcombe, 412 U.S. 17, 27 n.13 (1973). 
despite the arbitrary impact of a permissive scope of reprosecution rule in fostering the government's interest in deterring frivolous appeals and new trials, an indulgent court acting under the reasonableness standard might uphold reprosecution on the higher charges in deference to the state's interest in retaining the maximum tactical advantage at retrial.

\section{B. Strict Scrutiny}

Courts resort to the strict scrutiny test when the law employs a "suspect classification"137 or infringes on a "fundamental interest."188 When this standard is invoked, the state must show a "compelling interest" in upholding the law in order to overcome the presumption of unconstitutional classification. ${ }^{139}$ The rule being examined in this Comment does not fall within the accepted defimitions of a suspect classification; ${ }^{140}$ however, the rule does seem to touch an established fundamental interest. It is well settled that access to postconviction relief is a fundamental imterest of indigents. ${ }^{141}$ When addressing itself to discrimination against indigent appellants, the Supreme Court has repeatedly stressed the irrationality of wealth as a criterion for distinguishing frivolous from meritorious appeals. ${ }^{142}$ By implication, any defendant who is deterred from seeking an appeal for reasons completely unrelated to the merits of his potential appeal arguably lias suffered an infringement of his fundamental interest in access to postconviction relief. $^{143}$ Therefore, prospective plea-bargain appellants who forego their opportumity to correct an error in the guilty-plea proceedings for fear of being reindicted on the higher charges ${ }^{144}$ are capitulating to the infringement of a fundamental interest.

The language of the Constitution also argues for construing access to postconviction relief as a fundamental interest. The sixth amendinent provides for the right to a fair trial. Taking an appeal and attacking a conviction collaterally have been construed at the circuit-

137. See, e.g., McLaughlin v. Florida, 379 U.S. 184 (1964).

138. See, e.g., Skinner v. Oklahoma, 316 U.S. 535 (1942).

139. See Developments, supra note 122, at 1087-1132.

140. The accepted "suspect" classifications are race, lineage, and alienage. Developments, supra note 122, at 1088.

141. See cases cited in note 114 supra.

142. See cases cited in note 114 supra.

143. The rule which seeks to equalize access to appeal for indigents is premised on the notion that the right to fair trial cannot be effectively protected unless all meritorious appellants are freely entitled to an adjudication on the merits of their appeal or collateral attack. Therefore a rule which forecloses or substantially deters meritorious appeals abrogates the state's responsibility to provide a fair trial to all potentially meritorious appellants barred or dissuaded by the indiscriminate rule. Cf. Rinaldi v. Yeager, 384 U.S. 305, 309-10 (1966). But see note 19 supra.

144. See note 130 supra. 
court level to be procedural remedies for the assertion of the right to fair trial for those who were deprived of that right by prejudicial error at their original trial. ${ }^{145}$ The fundamental nature of this interest is underscored in the plea-bargain context because the issue on appeal usually is whether the defendant has inade a voluntary and knowing waiver of his constitutional rights, ${ }^{146}$ a matter of obvious constitutional concern.

What then is the state's compelling interest in being able to reindict successful plea-bargain appellants on the original, higher charges? Relieving the appellate courts of their clogged calendars by discouraging frivolous appeals is an argument that can always be put forward to forestall the expansion of access to postconviction relief. Yet the state's interest in limiting the burden of frivolous appeals was not sufficiently compelling to prevent the Supreme Court from lolding for expanded access in the indigent criminal appeal cases. ${ }^{147}$ More importtant, the state should not be permitted to claim that it has a compelling interest in treating defendants who pursue meritorious appeals to completion as a chastening example for those who might bring frivolous appeals to the court. ${ }^{148}$ The practical tension between offering postconviction relief and then subjecting the beneficiaries of that relief to a risk of greater punishment than unsuccessful appellants cannot logically be resolved into any compelling state interest. ${ }^{140}$ Finally, the constitutional dimension of the issues typically raised by appeals from plea bargains inveigh against any compelling interest claim of the need to deter the vindication of defendants' rights.

145. Patton v. State of North Carolina, 381 F.2d 636, 642 (4th Cir. 1967) cert. denied, 390 U.S. 905 (1968). For a perceptive discussion of the relationship between access to appeal and the right to fair trial, see Van Alstyne, supra note 8, at 613-36.

146. Van Alstyne [supra note 8] concedes in his article that the right to fair trial can be interpreted restrictively to refer to a trial free of constitutional error as distinguished from a trial free of any prejudicial error. See North Carolina v. Pearce, 395 U.S. 711, 739 (1969) (Black, J., concurring in part, and dissenting in part). Generally speaking, plea-bargain appeals would qualify as assertions of the more restrictively defined right to fair trial. See, e.g., North Carolina v. Pearce, 395 U.S. 711, 724 (1969).

147. See cases cited in note 114 supra.

148. This characterization of the state's interest borders on an announced policy of punishing defendants for winning an appeal or succeeding in a collateral attack, a policy which was deemed a violation of due process in North Carolina v. Pearce, 395 U.S. 711, 723-24 (1969).

149. [T] he very enactinent of two statutes side by side, one encouraging and granting appeals and another inaking it a crime to win an appeal, would be contrary to the very idea of government by law. It would create doubt, ambiguity, and uncertainty, making it impossible for citizens to know which one of the two conflicting laws to follow, and would thus violate one of the first principles of due process. Due process, moreover, is a guarantee that a man should be tried and convicted only in accordance with valid. laws of the land. If a conviction is not valid under these laws, statutory and con- 
The avoidance of new trials following plea-bargain convictions also fails the strict scrutiny test. The state will only be obliged to undertake new trials where the appeal is successful, that is, in only a small fraction of the cases where defendants seek postconviction review. ${ }^{150}$ And indeed, the likelihood of prevailing on a plea-bargain appeal is less than winning an appeal from a full-scale trial. ${ }^{161}$ The guilty-plea proceeding is much shorter and less complex than a trial; the judge need not rule on technical disputes over the admissibility of evidence or submit complicated instructions to the jury. In addition, the standard of voluntariness is quite liberally interpreted in favor of the prosecution when the defendant is represented by counsel. ${ }^{162}$ The cumulative weight of these factors would appear to defeat any attempt by the state to show it has a compelling interest in using reindictments on the higher charges to save the state the expense of trials for defendants who previously negotiated guilty-plea convictions.

The state's interest in a tactical advantage at trial, while nnore substantial than the deterrent interest, still falls well short of being compelling. The prosecutor enjoys counterbalancing tactical advantages. Although the prosecutor bears the burden of proof at the new trial, he is also in the better position to gather and preserve evidence and locate witnesses. The police department is placed at the prosecutor's disposal to assist in reconstructing the case against the defendant. In contrast, most defendants have no opportumity to do an investigation

stitutional, a man has been denied due process and has a constitutional right to have the conviction set aside, without being deprived of life, liberty or property as a result.

North Carolina v. Pearce, 395 U.S. 711, 738-39 (1969) (Black, J., concurring in part and dissenting in part) (1969).

150. In the federal courts of appeals, the overall rate of reversals was $13.4 \%$ in 1972. REPORTS OF THE PROCEEDINGS OF THE JUdicial CONFERENCE OF THE UNITED States, 1972 ANnual Report of the Director of the ADMinistrative OfFice of THE UNITED STATES CourTs at 94. According to the Judicial Council of California, of the approximately 6,200 postconviction petitions filed in California courts in fiscal 1968-69, roughly 5,300 were disposed of-i.e. denied-without either a formal hearing or written opinion. ... Interviews with various judges indicated that few applications produce the desired relief.

Judicial Council of California, 1971 Judicial Council Report, Part I, 31-32; accord, Fay v. Noia, 372 U.S. 391, 445 (1963) (Clark, J., dissenting) (Estimated $98 \%$ of habeas corpus petitions are frivolous). Given these low overall rates of success for criminal appellants and the recognized trend against granting postconviction relief to plea-bargain appellants [See Comment, Post-Conviction Relief From Pleas of Guilty: A Diminishing Right, 38 BROoKLYN L. REv. 182 (1972) (hereinafter cited as Post-Conviction Relief)], it is reasonable to assume that a relatively small proportion of plea-bargain appellants succeed in winning a new trial.

151. See also Post-Conviction Relief, supra note 150.

152. See, e.g., McMann v. Richardson, 397 U.S. 759 (1970) (Prior coerced conviction held not to vitiate the voluntariness of a plea where the defendant was represented by counsel). The most recent analysis of this trend toward insulating plea bargains from sụcçesșful appeal appears ịn Post-Conviçtion Relief, supra note 150, 
in their own behalf; furthermore the defendant's time spent in prison will often isolate and alienate him from the people who might be able to help him prepare an alibi or provide the jury with insight into extenuating circumstances. ${ }^{153}$ This disparity in resources for trial preparation undermines the prosecutor's contention that the state has a compelling interest in reindicting on the maximum charges to protect itself from compromise verdicts. ${ }^{154}$

The strict scrutiny test is normally complemented by the rule that the classification scheme be closely tailored to realization of the compelling interest asserted by the state. ${ }^{155}$ This complementary rule gives rise to the issues of underinclusiveness and overinclusiveness which Professor Gunther associates with the emerging standard of equal protection review, "intensified means scrutiny". Given the similarity of the issues raised, the complement to the strict scrutiny test will simply be imcorporated by implication into the discussion and application of "intensified means scrutiny."

\section{Intensified Means Scrutiny}

Professor Gunther's model of the equal protection standard of review being formulated by the current Court reflects a middle ground between the reasonableness test and the strict scrutiny standard. ${ }^{156} \mathrm{He}$ believes the Court is seeking to avoid substantive judgments on the propriety of legislative ends-judgments which are implicit in weighing legislative ends against the Court's sense of fundamental interestsby focusing greater attention on the reasonableness of the means the legislature has selected to achieve a given objective. This focus on the means requires the state to show more than just any reasonable basis for its classification, but it spares the state from the burden of meeting the almost insurmountable compelling interest standard. ${ }^{157}$

153. Cf. The President's Commission on LAW ENForcement and AdministraTION OF JUSTICE, TASK FORCE REPORT: CORRECTIONS 46 (1967).

154. See, e.g., North Carolina v. Pearce, 395 U.S. 711, 714 n.4 (1969). In Simpson $v$. Rice, the companion case to Pearce, the defendant was retried on only three of the four burglary counts to which he had originally pleaded guilty. The fourth count was dropped because the chief witness for the prosecution had left the state. Nevertheless the prosecutor was able to obtain convictions on all of the three remaining counts and persuade the judge to increase the defendant's sentenee from 10 to 25 years.

155. See, e.g., Harper v. Virginia State Bd. of Elections, 383 U.S. 663, 670 (1966); Carrington v. Rash, 380 U.S. 89 (1965); Skinner v. Oklahoma, 316 U.S. 535, 541 (1942). Of course, a court which recognized the arbitrariness of the rule permitting reindictment on the higher charges with respect to the government's interest in deterring frivolous appeals and new trials for plea-bargain defendants would a fortiori conclude that the rule is not closely enough tailored to serving these interests to satisfy the strict scrutiny standard; of. text accompanying notes 130-34 supra.

156. See Gunther, supra note 123 , at 24.

157. Korematsu v. United States, 323 U.S. 214 (1944). 
On isolated occasions the Warren Court used a means-oriented equal protection technique which presaged the "intensified means scrutiny" now favored by the Burger Court. ${ }^{158}$ Rinaldi v. Yeager ${ }^{150}$ represents one of those occasions. Rinaldi involved a state law which had the effect of inhibiting access to postconviction rehef. Thus, a discussion of the case will be useful as an application of the standard of intensified means scrutiny in the context of the same general policy considerations as those raised by reprosecution of plea-bargain appellants on higher charges.

In Rinaldi, the Court invalidated a law which required that state prisoners who unsuccessfully appealed in forma pauperis reimburse the state for the cost of providing a transcript to the indigent appellant. ${ }^{160}$ Rinaldi, an unsuccessful appellant who had become $h-$ able to the state for the cost of his transcript, argued that the state should not be permitted to limit the indigent's opportunity to appeal "by saddling him with the obligation of paying for the cost of a transcript."161 Rinaldi asked the Court to extend the suspect classification and fundamental interest scrutiny of Griffin $v$. Illinois ${ }^{162}$ and its prog$e^{e n y^{163}}$ to the reimbursement law in question. The Court refused ${ }^{104}$ and proceeded to analyze the case in terms of the relationship between the means and the purposes of the law.

Relying on the title of the law and the state's brief, the Court identified two possible legislative purposes, reimbursement of the state and deterrence of frivolous appeals. ${ }^{165}$ The Court did not question the wisdom of these purposes nor weigh them against any other interests. However, the Court did state that equal protection requires that the classification scheme have "some," as distinguished from just "any," reasonable relation to the purpose of the legislation. ${ }^{106}$ With respect to the purpose of reimbursement, the Court found the classification underinclusive because it did not impose the cost of a transcript on indigent unsuccessful appellants who were only sentenced to pay fines or who were given probation or a suspended sentence. Although the nature of the pumishment varied among these different types of unsuc-

158. See Gunther, supra note 123, at 27.

159. 384 U.S. 305 (1966).

160. Id. at $310-11$.

161. Id. at 307. The cost of the transcript was $\$ 215.00$. Rinaldi was compensated for his prison work at a rate of 20 cents a day, five days a week. In order to reimburse the county, Rinaldi would be deprived of his earnings for a period of approximately four years, one month, and three weeks. Id. at 306.

162. 351 U.S. 12 (1956).

163. See cases cited in note 114 supra.

164. Rinaldi v. Yeager, 384 U.S. 305, 307-08 (1966).

165. Id. at $309-11$.

166. Id. at 309 . 
cessful appellants, provision of their transcripts placed the same drain on the county treasury. In relation to the goal of deterring frivolous appeals, the Court found the classification both overinclusive and underinclusive. Imposing the transcript cost on all unsuccessful appellants resulted in a financial burden on those whose unsuccessful appeals were frivolous as well as those whose appeals were unsuccessful, but not necessarily frivolous. The rule was underinclusive in that it left untouched those appellants who were not inmates but had pressed frivolous appeals. In conclusion, the Court acknowledged the state's right to provide for recoupment of the cost of appeals but insisted that under the equal protection clause the means adopted must operate on similarly situated groups in an evenhanded way. ${ }^{107}$

This means-oriented equal protection standard can readily be applied to the rule permitting reprosecution on the higher charges following reversal of a plea-bargain conviction. If the purpose of the rule is to deter frivolous appeals, the rule is both overinclusive and underinclusive. The deterrent effect of the rule ${ }^{168}$ goes beyond the class of individuals who succeed on appeal and face the threat of larsher punishment after retrial. The rule imevitably deters many prospective appellants, and its broad impact does not distinguish between meritorious and frivolous appeals. As a result, the rule is overinclusive. ${ }^{189}$

The rule is underinclusive insofar as the only appellants who suffer from its application are those who have brought successful appeals. Consequently, the rule is most effective as a sanction against the potential appellant who has suffered the nnost grievous abuse of his rights in the plea-bargaining process. Iromically, the truly frivolous appellant has the least to fear because of the remoteness of the possibility that he will obtain a new trial. Also, frivolous appellants who liave been convicted of a lesser offense as a consequence of a trial are not deterred by this rule. The trial appellants, who imcidentally enjoy a wider selection of frivolous issues on appeal, ${ }^{170}$ are insulated froin reprosecution on higher charges as a result of the double jeopardy principles announced in Green v. United States. ${ }^{171}$

The most dramatic example of the rule's underinclusiveness stems from the likelihood that defendant Rice in North Carolina v. Pedrce $e^{172}$

167. Id. at 311.

168. See note 130 supra.

169. If the class affected by the rule is defined more broadly to include all pleabargain appellants, it would still be overinclusive insofar as it deterred prospective meritorious, applicants from appealing.

170. See text accompanying notes 151-52 supra.

171. 355 U.S. 184 (1957).

172. 395 U.S. 711 (1969). This dimension of underinclusiveness also applies if the class affected by the rule is defined as all plea-bargain appellants. 
was a successful plea-bargain appellant. ${ }^{173}$ As will be recalled, the Court in Pearce held that Rice could not be subjected to harsher punishment after successful appeal and conviction at retrial unless the justification for the increased sentence was based on "objective information concerning identifiable conduct occurring after the time of the original sentencing proceeding." "174 This rule will greatly restrict, if not eliminate, harsher sentences for successful appellants convicted at retrial of the saine offense.

Plea-bargain concessions normally involve dismissal of the charges in a inultiple-count indictment, acceptance of a plea to a lesser-included offense, or a recommendation of sentencing leniency by the prosecutor. ${ }^{175}$ Quite possibly Rice was the beneficiary of a guilty plea exchanged for a lenient sentence recommendation. ${ }^{178}$ If so, successful plea-bargain appellants who have opted for sentence leniency ${ }^{177}$ are substantially more insulated fron the risk of higher punishment following retrial than the other types of plea-bargain appellants. ${ }^{178}$

This discriminatory treatment of the various types of plea-bargain appellants ineans that the rule permitting reprosecution on the higher charges will not deter frivolous appeals by plea-bargain appellants who had originally bargained for sentence leniency. Furthermore, with respect to the state's interest in minimizing new trials and enjoying a tactical advantage at retrial of plea-bargain appellants, reprosecution on the higher charges is an ineffective sanction against appellants who negotiated sentence leniency pleas and thereby qualified for the shelter

173. United States ex rel. Williams v. McMann, 436 F.2d 103, 107 (2d Cir. 1970) (Hays, J, concurring), cert. denied, 402 U.S. 914 (1971). See note 16 supra.

174. Pearce v. North Carolina, 395 U.S. 711, 726 (1969).

175. NewMan, supra note 53, at 97. Newnian also mentions "avoidance of prosecution under statutes which conpound either the conviction label (sexual psychopath) or sentence (habitual offender) or both" as a common type of plea-bargain concession. For an informative general description and analysis of plea bargaining in California, see Comment, Judicial Supervision Over California Plea Bargaining: Regulating the Trade, 59 CALIF. L. REV. 962 (1971).

176. See note 173 supra.

177. In Newnuan's work on plea bargaining, he explains that varying schemes of classifying criminal offenses and differences in sentencing structures affect the nature of the concessions that will be sought by a plea-bargain defendant. In jurisdictions where judges have ninimum discretion in setting the sentence for particular offenses, the defendant will be more likely to ask for a charge reduction than a recon1mendation of sentencing leniency. By contrast, where the judge enjoys broad sentencing discretion, the defendant is nore interested in bargaining for sentencing leniency. Newman, supra note 53, at 78-90.

178. Courts can make the distinction that one of these groups is being retried for the same offense and the other is being retried for a higher or additional offense [see, e.g., United States ex rel. Williams v. McMann, 436 F.2d 103, 105 (2d Cir. 1970), cert. denied, 402 U.S. 914 (1971)], but this legalistic nicety ignores the practical similarity of all plea-bargain defendants seeking post-conviction review. See note 30 supra. 
of the Pearce rule. These plea-bargain appellants need not weigh the threat of reprosecution on higher charges before seeking a new trial, and they will recognize that the prosecutor's tactical discretion is largely limited to obtaining the same punishment as that imposed at the original guilty-plea proceeding. By contrast, the other types of successful plea-bargain appellants remain vulnerable to reindictment on the higher charges, and the prosecutor is given a free hand to use his greater charging power as a tactical weapon at retrial.

A recurrent theme emerges from applying the standard of intensified means scrutiny. Distinctions are being made between various classes of potential and actual criminal appellants which are not reasonably related to the purposes of the rule. Therefore the rule of remdictment on the higher charges, like the statute invalidated in Rinaldi $v$. Yeager, ${ }^{179}$ violates the equal protection clause of the Constitution.

\section{CONCLUSION}

The constitutional implications of the rule permitting reindictment of successful plea-bargain appellants on the original, higher charges have been explored as questions of due process, double jeopardy, and equal protection. Using the absence of vindictive motive as the relevant due process test leads to the conclusion that due process is violated by allowing reprosecution on the higher charges. Courts which have reached the opposite conclusion have done so by importing contract rules which obfuscate the vimdictiveness issue. Moreover, courts fail to view the reprosecution rule as a condition of an adhesion contract which should be deemed unenforceable as a contravention of public policy. The double jeopardy approach to the reprosecution problem does not expose the unconstitutionality of the reprosecution rule. A violation of double jeopardy in this context requires the attaching of jeopardy on the higher offense and an implied acquittal. The defendant who submits a guilty plea to a lesser offense than charged in the indictment is not in peril of conviction of the higher offense; therefore jeopardy never attaches on the higher charge. The doctrine of implied acquittal cannot be extended to the plea-bargain situation because the judge's factual inquiry is limited to determining voluntariness. This process cannot be equated with the fact-finding basis of an imphied acquittal where the judge or jury at trial seeks to classify the defendant's conduct in relation to all the charges in the indictment. Whether reindicting on the higher charges is constitutional under the equal protection clause depends on the standard of review which is applied. The rule would be valid under the simple reasonableness stand-

179. 384 U.S. 305 (1966). 
ard on the ground that it promotes the state's interest in providing prosecutors with a tactical advantage at the retrial of successful pleabargain appellants. However, the rule offends equal protection when tested against the strict scrutiny or the emerging intensified means standard. The state's interest in a tactical advantage at retrial is not sufficiently compelling to satisfy strict scrutiny. Measured by the intensified means standard, the impact of the rule is both overinclusive and underinclusive. In connection with the state's interest in deterring frivolous appeals and new trials following plea bargains, the rule affects meritorious and frivolous appellants alike. As for the state's interest. in a tactical advantage, the reprosecution rule appears to omit the substantial number of plea-bargain appellants whose pleas are based on sentence lemiency recommendations. In sum, a court relying on the due process clause or invoking the strict scrutiny or intensified ineans standard of equal protection should hold that the rule permitting reprosecution of successful plea-bargain appellants on the original, higher charges is unconstitutional.

The unost obvious practical consideration raised by limiting the scope of reprosecution to the original conviction is opening the floodgates and inundating the courts with criminal appeals. The burden on the appellate courts is a legitimate concern which affects the quality of justice available to all appellants. ${ }^{180}$ However, equal protection and due process both require that the winnowing of the appellate caseload be done on a rational basis which does not penalize meritorious appellants solely because they admitted their guilt. ${ }^{181}$

Where the defendant has pleaded guilty to a related offense which includes an element that does not correspond to the actual facts another practical obstacle is encountered. For example, in some jurisdictions a defendant charged with burglary at night will plead guilty to a charge of daytime burglary. ${ }^{182}$ Under those circumstances, the prosecution may not be able to prove daytime burglary at the retrial following the defendant's appeal. In such cases, the system should be flexible enough to permit reprosecution on the original charges while imstructing the judge to limit the punishment meted out to that agreed to under the plea bargain. ${ }^{183}$

Opponents of limiting the scope of reprosecution might also contend that changing the rule in favor of defendants will deter prosecu-

180. See Carrington, supra note 127 , at 554-56.

181. Cf. Van Alstyne, supra note 8, at 623.

182. NEwMan, supra note 53 , at 100-01.

183. A similar approach could be used to handle the plea to a nonexistent offense. See note 52 supra. Justice Stewart acknowledged the reasonableness of this type of flexibility as a limitation on punishment for successful appellants in his dissenting opinion in Chaffin v. Stynchcombe, 412 U.S. 17, 37 (1973). 
tors from plea bargaining. But this possibility seems remote. In a society where 70 to 90 percent of all felony convictions are based on plea bargains, ${ }^{184}$ prosecutors lack the flexibility to abolish the system in response to a change in the permissible scope of reprosecution. The least burdensome adjustment for all concerned would be the development of a record of the plea bargain by the judge and the prosecutor which clearly documents the constitutional propriety of the proceedings. ${ }^{185}$ Admittedly, the danger exists that prosecutors will react by bargaining for stiffer terms. Hopefully, a vindictive response at the bargaining level would be tempered by the realization that only a small fraction of plea-bargain appellants will actually succeed in winning new trials. $^{180}$

Permitting vindictive prosecutors to impede access to appeal for the plea-bargain convict causes the great majority of the prison population to endure their sentence in the knowledge that a forbidding price inust be paid to vindicate the right to a fair trial. Finally, courts should realize that the alternative to limiting the scope of reprosecution to the origimal, plea-bargain conviction is the continuation of a system which relegates the plea-bargain convict to the status of a secondclass appellant.

Thomas S. Williamson, Jr.

184. See note 1 supra.

185. For a more detailed discussion of the importance of a well developed record in plea-bargain cases see NEWMAN, supra note 53, at 218-23.

186. See note 150 supra. 